\title{
Ownership Structure, Accounting Information Quality and Investment Efficiency: An Empirical Study Based on Chinese Agricultural Listed Companies
}

\author{
Fanyi Li \\ School of Management, Sichuan Agricultural University, Chengdu, Sichuan, P.R. China \\ Irsnow@aliyun.com
}

Keywords: Accounting Information Quality, Ownership Structure, Inefficient Investment.

\begin{abstract}
The irrational investment in the development of agricultural listed companies leads to low investment efficiency and slow development. In order to explore the inefficient investment of agricultural listed companies, this paper uses China's Shanghai and Shenzhen stock A 47 agricultural listed companies from 2013-2015 to analyze the relationship between the quality of accounting information and the inefficient investment of agricultural listed companies, and also the influence of ownership structure on the quality of accounting information and the efficiency of agricultural listed companies. The study found that when the quality of enterprise accounting information is high, the inefficient investment behavior of enterprises is improved, thus improving the efficiency of enterprise investment; the increase of controlling shareholder's equity will weaken the governance effect of accounting information quality on inefficient investment.
\end{abstract}

\section{Introduction}

For a long time, agriculture has always been a central concern of the central government. As a representative of China's advanced agricultural productivity and advanced forms of agricultural development, agricultural listed companies play key roles in promoting agricultural industrialization in China. However, investment irrationality is inevitable in the process of the development of agricultural listed companies, such as inadequate investment and excessive investment. These unreasonable problems will inevitably affect the investment efficiency of such companies.

As one of the important tools of financial decision-making, accounting information is accessible, transparent, and standardized. It is an important indicator for enterprises to make effective investment decisions. Ownership structure also affects the investment behavior of enterprises, the large scale and deep involvement of controlling shareholders in agricultural listed companies often lead to excessive investment or underinvestment, resulting in inefficient investment. The analysis of the investment efficiency of agricultural listed companies can provide some theoretical support and technical guidance to make rational investment, make efficient use of resources, improve investment efficiency and expand development strength.

\section{Theoretical Analysis and Research Hypothesis}

The influence of the quality of accounting information on investment efficiency. High quality accounting information can alleviate the information asymmetry in capital market and reduce the distortion of resource allocation [1,2]. The disclosure of accounting information in the capital market can reflect the operation of the enterprise more accurately, and enable the shareholders and creditors to have more information about the investment projects, it can effectively reduce adverse selection and liquidity risk, reduce financing costs, and reduce the investment shortage caused by financing constraints, so as to guide enterprises to invest rationally.

The governance function of accounting information can reduce the inefficient investment caused by principal-agent problems. Accounting information alleviated agency conflicts between shareholders and management, and reduced agency costs, it is a kind of mechanism that can regulate 
the investment behavior of managers, and can effectively restrain the occurrence of inefficient investment behavior, and its application in the compensation contract is the most representative of the governance function [3]. Richardson tested the inefficient investment and the free cash flow hypothesis with the expectation model. Based on the above analysis, this paper presents the first hypothesis:

H1: In China's agricultural listed companies, the quality of accounting information is negatively related to the inefficient investment behavior of enterprises.

The influence of the quality of accounting information on investment efficiency from the perspective of ownership structure. The ownership structure reflects the different governance structure of the enterprise, which determines the distribution of the relevant rights in the decision-making process, can the efficiency of internal governance mechanisms affect the company's internal incentive of managers and other companies, which influence the company accounting information quality to enhance the efficiency of investment. It can affect the efficiency of the internal governance mechanism of the company, and thus affect the quality of the company's accounting information and enhance the efficiency of investment.

In 1930s, American economists Berle and Means come up with the "principal-agent theory" promote the separation of ownership and management rights; enterprise owners transfer the right to operate. However, with the increase of the proportion of the large shareholder, the problem begins to shift to the conflict of interest between the large shareholders and minority shareholders. The more concentrated the controlling shareholder's equity, the stronger the control to the listed company, the more difficult the behavior is to the supervision by the small and medium-sized shareholders, which leads to the decline of the company's performance. Based on the above analysis, second hypotheses are proposed in this paper:

$\mathrm{H} 2$ : In China's agricultural listed companies, with the increase of the shareholding of controlling shareholders, the inhibitory effect of accounting information quality on non-investment efficiency investment will be weaken.

\section{Empirical Research}

Sample Selection and Data Sources. In this paper, we chose China's Shanghai and Shenzhen stock A 47 agricultural listed companies from 2013-2015 as the research object. Since the calculation of some variables requires the data of the previous and post periods, the actual data for this study is from 2011 to 2016. At the same time, samples are selected according to the following criteria:

(1) Exclude ST/ PT agricultural listed companies and those companies with incomplete data;

(2) Exclude agricultural listed companies listed on B shares and H shares simultaneously;

(3) Exclude agricultural listed companies listed after 2011;

The data required in this article is from the CSMAR database. In order to eliminate the influence of outliers, the data of the main variables were processed with $1 \%$ winsorization.

\section{Variable Definition and Model Building}

Explained Variable. Investment Efficiency (Inv). This paper uses Richardson [4] investment efficiency model as basic model to measure inefficient investment of agricultural listed companies. Combining the characteristics of these companies, the basic form of the final model is as follows:

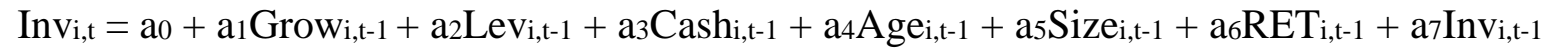

$$
\begin{aligned}
& +\sum \text { Year }+\mu_{\mathrm{i}, \mathrm{t}} \text {. }
\end{aligned}
$$

In Eq. 1, Inv indicates the level of investment in an enterprise, which is the absolute value of regression residuals in model (1); Grow represents the growth of an enterprise; Lev is the asset liability ratio; Cash represents cash holding levels; Age stands for the years listed on the enterprise; Size for enterprise size; RET represents the profitability of an enterprise, $\mu_{\mathrm{i}, \mathrm{t}}$ is residual, if it is greater 
than 0 , said the enterprise over investment, denoted as OverI; if the residual error is less than 0 , said the lack of investment, denoted as UnderI.

Explanatory Variable. Accruals Quality (AQ). This paper uses Dechow and Dichev (2002) model to measure the quality of accounting information, and AQ is the inverse of the absolute value of the residual term obtained from D\&D model. Eq. 2 is as follows:

$\Delta \mathrm{WC}_{\mathrm{i}, \mathrm{t}}=\beta_{0}+\beta_{1} \mathrm{CFO}_{\mathrm{i}, \mathrm{t}-1}+\beta_{2} \mathrm{CFO}_{\mathrm{i}, \mathrm{t}}+\beta_{3} \mathrm{CFO}_{\mathrm{i}, \mathrm{t}+\mathrm{t}}+\mu_{\mathrm{i}, \mathrm{t}}$.

$\triangle W C_{i, t}$ represents the change in working capital of company $i$ in the year $t ; C F O_{i, t-1} 、 C F O_{i, t}$ 、 $C F O_{i, t+1}$ represent the ratio of operating cash flows to current total assets of the company in $t-1, t$ and $t+1$, respectively. $\mu_{\mathrm{i}, t}$ is residual which deals with absolute values and inverse numbers. The higher the numerical value, the higher the quality of accounting information.

The Ownership Concentration of an enterprise reflects the concentration and dispersion of the equity in an enterprise, and is an important yardstick to measure the efficiency of an enterprise's investment. In this paper, the Controlling Shareholder Equity Ratio (CRl) and the Ownership Concentration Ratio ( $Z$ index) are chosen to represent the Ownership Concentration, where CRI refers to shareholding ratio of the largest shareholder and $Z$ index represents the proportion of the largest shareholder/the proportion of the second major shareholders.

Control Variable. Based on past research experience, Asset Liability Ratio (Lev) and Enterprise Scale (Size) are chosen as control variables. Lev is calculated as Ending Total Liabilities/Ending Total Asset, and Size is computed via Main Business Income / Initial Total Assets.

Model Constructing. Eq. 3 is mainly used to analyze the relationship between Inefficient Investment and the Accounting Information Quality, Eq. 4 and Eq. 5 mainly focus on the Ownership Concentration, and analyze its impact on the quality of accounting information.

$$
\begin{aligned}
& \operatorname{Inv}=\mathrm{a}_{0}+\mathrm{a}_{1} \mathrm{AQ}_{\mathrm{i}, \mathrm{t}}+\mathrm{a}_{2} \text { Size }_{\mathrm{i}, \mathrm{t}-1}+\mathrm{a}_{3} \mathrm{Lev}_{\mathrm{i}, \mathrm{t}-1}+\sum \text { Year }+\mu_{\mathrm{i}, \mathrm{t}} \\
& \operatorname{Inv}=\mathrm{a}_{0}+\mathrm{a}_{1} A \mathrm{Q}_{\mathrm{i}, \mathrm{t}}+\mathrm{a}_{2} \mathrm{CR} 1+\mathrm{a}_{3} \mathrm{CR} 1 \times \mathrm{AQ}_{\mathrm{i}, \mathrm{t}}+\mathrm{a}_{4} \mathrm{Size}_{\mathrm{i}, \mathrm{t}-1}+\mathrm{a}_{5} \mathrm{Lev}_{\mathrm{i}, \mathrm{t}-1}+\sum \text { Year }+\mu_{\mathrm{i}, \mathrm{t}} . \\
& \operatorname{Inv}=\mathrm{a}_{0}+\mathrm{a}_{1} A \mathrm{Q}_{\mathrm{i}, \mathrm{t}}+\mathrm{a}_{2} \mathrm{Z}+\mathrm{a}_{3} \mathrm{Z} \times \mathrm{AQ}_{\mathrm{i}, \mathrm{t}}+\mathrm{a}_{4} \operatorname{Size}_{\mathrm{i}, \mathrm{t}-1}+\mathrm{a}_{5} \mathrm{Lev}_{\mathrm{i}, \mathrm{t}-1}+\sum \text { Year }+\mu_{\mathrm{i}, \mathrm{t}} .
\end{aligned}
$$

\section{Empirical Results and Analysis}

Descriptive Statistics. There are 76 agricultural listed companies with lack of investment, which account for $53.9 \%$ of total sample. In contrast, there are 65 agricultural listed companies with excessive investment, which account for $46.1 \%$ of total sample. The results show that there is little difference between the underinvestment and overinvestment in the non-investment efficiency of agricultural listed companies in China. The mean and median values of UnderI are very close, which is -0.058476 and -0.04502 respectively, and the standard deviation is 0.056112 . The average and median values of OverI are similar, and the standard deviation is 0.056917 . The average and median values of AQ are 0.120542 and -0.09761 respectively, which shows that the distribution of accounting information quality is relatively homogeneous.

Empirical analysis. As shown in Table 1, Eq. 3 passed the F-test. The results show that in the sample, underinvestment is significantly negatively related to accruals quality at $1 \%$ level, and $\mathrm{R}$-squared is 0.4226 , meaning that if agricultural listed companies improve the quality of their accounting information, they can effectively alleviate insufficient investment. The empirical results validate hypothesis 1 .

Eq. 4 passed the F-test. It shows that there is no significant correlation between underinvestment and accruals quality. However, the shareholding ratio of controlling shareholders is significantly negatively correlated with underinvestment at 5\% level, and CR1 $\times$ AQ cross term is negatively related to underinvestment, the $\mathrm{R}$ - squared is 0.4218 . The results reflect that the relationship between the lack of investment and accruals quality is affected by the holding ratio of the biggest shareholder in a certain extent. The greater the proportion of controlling shareholders, the smaller the shortage of 
investments. However, the proportion of controlling shareholders did not mitigate the effect of accruals quality on the underinvestment of enterprises.

Eq. 5 passed the F-test, and the R-squared is 0.4265 . It shows there is a negative correlation between underinvestment and accruals quality, which is significant at the level of $1 \%$. The correlation coefficient of Z×AQ cross term is negative, and it is also negatively related to underinvestment. However, the sensitivity of the quality of the investment to the corresponding meter is reduced. From this we can see that the more concentrated the equity, the more likely the decline of the quality of the enterprise's accounting information will be. This conclusion is consistent with the hypothesis 2 .

Table 1 Regression of Underinvestment and Accruals Quality

\begin{tabular}{|c|c|c|c|c|c|c|c|c|c|}
\hline \multirow{2}{*}{ Variable } & \multicolumn{3}{|c|}{ Eq. 3} & \multicolumn{3}{|c|}{ Eq. 4} & \multicolumn{3}{|c|}{ Eq. 5} \\
\hline & Coefficient & $\mathrm{t}$ & $P>|t|$ & Coefficient & $\mathrm{t}$ & $P>|t|$ & Coefficient & $\mathrm{t}$ & $\mathrm{P}>|\mathrm{t}|$ \\
\hline Constant & -0.082608 & -3.23 & 0.002 & -0.086980 & -2.64 & 0.010 & -0.086980 & -2.64 & 0.010 \\
\hline $\mathrm{AQ}$ & -0.083320 & -3.31 & 0.001 & -0.235124 & -1.01 & 0.315 & -0.083952 & -3.37 & 0.001 \\
\hline Size & 0.003589 & 2.42 & 0.031 & 0.004176 & 2.37 & 0.036 & 0.004242 & 2.40 & 0.032 \\
\hline Lev & -0.093096 & -2.32 & 0.023 & -0.080972 & -1.98 & 0.052 & -0.098325 & -2.35 & 0.022 \\
\hline CR1 & - & - & - & -0.032366 & -2.43 & 0.030 & - & - & - \\
\hline CR1×AQ & - & - & - & -0.392146 & -2.54 & 0.028 & - & - & - \\
\hline $\mathrm{Z}$ & - & - & - & - & - & - & -0.000127 & -2.61 & 0.012 \\
\hline $\mathrm{Z} \times \mathrm{AQ}$ & - & - & - & - & - & - & 0.000199 & 2.54 & 0.017 \\
\hline R Square & \multicolumn{3}{|c|}{0.4226} & \multicolumn{3}{|c|}{0.4218} & \multicolumn{3}{|c|}{0.4265} \\
\hline $\mathrm{F}$ & \multicolumn{3}{|c|}{17.259} & \multicolumn{3}{|c|}{15.093} & \multicolumn{3}{|c|}{.151} \\
\hline
\end{tabular}

As can be seen from Table 2, Eq. 3 passed the F-test. R-squared is 0.3517 . The results show that over investment has a significant negative correlation with accruals quality at the level of $1 \%$, which means the improvement of the quality of accounting information will help enterprises avoid excessive investment and effectively improve their investment efficiency. This conclusion supports hypothesis 1.

Eq. 4 passed the F-test. R-squared is 0.3506 . There is no significant correlation between accruals quality, the proportion of controlling shareholders and overinvestment. The cross correlation coefficient of CR $1 \times A Q$ was positive, but still not significant. It shows that the change of the shareholding ratio of controlling shareholder does not affect the relationship between the quality of accounting information and over investment.

Eq. 5 passed the F-test. R-squared is 0.3529 . The results show that overinvestment is negatively related to accruals quality, while equity concentration is not significantly related to overinvestment. $Z$ correlation coefficient was positive, but not significant. It shows that the controlling power of the controlling shareholder does not affect the phenomenon of excessive investment. However, the correlation coefficient of $\mathrm{Z} \times \mathrm{AQ}$ cross term is positive and significant. It shows that the quality of accounting information will weaken the excessive investment as the controlling shareholder's equity increase. This conclusion is consistent with the hypothesis 2 . 
Table 2 Regression Results of Overinvestment and Accruals Quality

\begin{tabular}{|c|c|c|c|c|c|c|c|c|c|}
\hline \multirow{2}{*}{ Variable } & \multicolumn{3}{|c|}{ Eq. 3 } & \multicolumn{3}{c|}{ Eq. 4 } & \multicolumn{3}{c|}{ Eq. 5 } \\
\cline { 2 - 11 } & Coefficient & $\mathrm{t}$ & $\mathrm{P}>|\mathrm{t}|$ & Coefficient & $\mathrm{t}$ & $\mathrm{P}>|\mathrm{t}|$ & Coefficient & $\mathrm{t}$ & $\mathrm{P}>|\mathrm{t}|$ \\
\hline Constant & 0.066878 & 2.61 & 0.012 & 0.019855 & 0.55 & 0.585 & 0.047597 & 1.78 & 0.080 \\
\hline AQ & -0.046347 & -3.30 & 0.001 & -0.430439 & -1.12 & 0.298 & -0.155432 & -3.17 & 0.002 \\
\hline Size & 0.004252 & 2.36 & 0.035 & 0.006188 & 2.39 & 0.034 & 0.000561 & 2.29 & 0.037 \\
\hline Lev & -0.005516 & 2.55 & 0.028 & -0.004346 & -2.56 & 0.027 & -0.098325 & -2.60 & 0.024 \\
\hline CR1 & - & - & - & 0.145639 & 1.92 & 0.065 & - & - & - \\
\hline CR1*AQ & - & - & - & 1.109714 & 1.81 & 0.075 & - & - & - \\
\hline Z & - & - & - & - & - & - & 0.000928 & 1.70 & 0.095 \\
\hline$Z^{*}$ AQ & - & - & - & - & - & - & 0.007274 & 2.00 & 0.047 \\
\hline R Square & \multicolumn{3}{|c|}{0.3517} & & \multicolumn{3}{|c|}{0.3506} & & \multicolumn{3}{c|}{0.3529} & 13.816 \\
\hline F & \multicolumn{3}{|c|}{14.724} & \multicolumn{3}{|c|}{13.473} \\
\hline
\end{tabular}

\section{Research Conclusions and Recommendations}

This paper uses 47 listed agricultural companies of a shares in China from 2013-2015 to examine the relationship between the quality of accounting information and ownership structure and inefficient investment of agricultural list companies in China. Main conclusions are as follows. First, there is a negative correlation between the quality of accounting information and inefficient investment in agricultural enterprises, meanwhile, the improvement of the quality of accounting information can effectively alleviate the low efficiency of investment. Second, there is no significant correlation between accruals quality, the proportion of controlling shareholders and overinvestment, the shareholding ratio of controlling shareholders has no influence on the relationship between the quality of accounting information and inefficient investment. But considering the controlling power of the controlling shareholder, with the increase of the controlling shareholder's equity, the effect of the quality of accounting information on the inefficient investment is weakened.

Since the quality of accounting information for efficient investment of agricultural listed companies impose a positive impact, if the quality of information disclosure is improved and the supervision of information disclosure is reinforced, then accounting information can perform better in the allocation of resources.

For the internal governance structure, we should establish a sound and perfect internal management system to ensure the accuracy and integrity of accounting information, and effectively improve the quality of accounting information. At the same time, to effectively avoid large shareholders' influence on decision-making, agricultural listed companies should be reduced properly by proportion of the first largest shareholder, scattered shareholder rights, promote equity balance play an effective role, and ultimately promote the efficiency of the allocation of resources to improve.

\section{References}

[1] S.C. Myers, N.S. Majluf: Corporate Financing and Investment Division When Firm Have Information the Investor Do Not Have. Journal of Financial Economic. Forum Vol. 13 (1984), p. 187-221.

[2] M. Jensen: Agency Costs of Free Cash Flow, Corporate Finance, and Takeover. American Economic Review. Forum Vol. 76 (1986), p. 323-329.

[3] R. Bushman, A. Smith: Financial accounting information and corporate governance. Journal of Accounting and Economics. Forum Vol. 32 (2001), p. 281-302. 